\title{
Swedish One-Man Saws
}

From the Article in "Skogen," May 1926, By MR. GUSTAF LUNDBERG.

In Swedish logging, especially in the northern and middle parts of the country, the old-fashioned twoman saw has been almost entirely superseded by the one-man saw, with which most of the cutting is now done.

The reason for this is that the average size of the trees cut hlas been getting smaller, and the single sawthe one-man saw-has been improved continually and has now attained perfection. Thus, two cutters, each working alone with single saws in a forest of ordinary sized trees, actually are doing better work than two men working together with a double saw.

There is also a matter of psychology-two workers would rathier work singly than together. A man working alone and getting the profit of his work himself, is

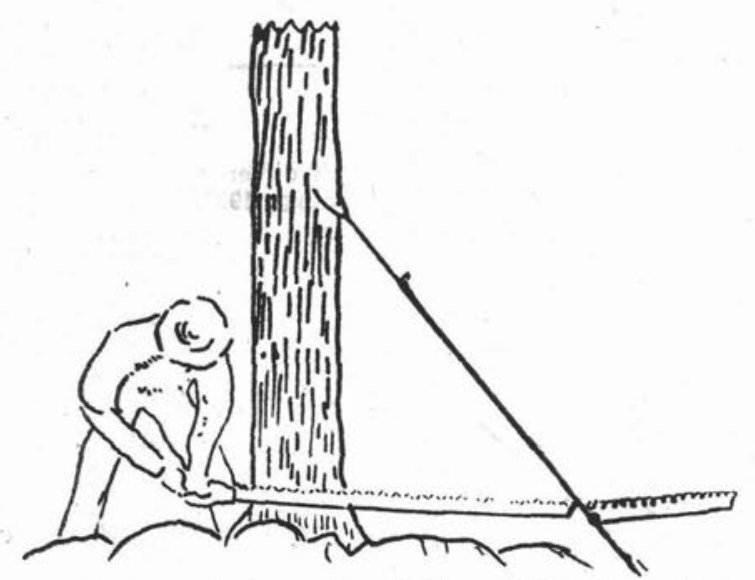

Fie. 1. The Kompisapparat used for cutting down trees.

anxious to do his best, since he gets the whole profit of his work, rather than eventually having to divide it with his companion. Thus, as the single saw is more widely used, not only is the amount of work done inereased, but the working intensity is also increased.

The improvement in efficiency of the single saw has consisted chiefly in making more suitable teeth for the saw-irregular teeth with eutting edges suited to oneway eutting blades; with height of the teeth and distance between them properly guaged; and also in making the saw blade thinner and more elastic. It has been proved in practice as well as in theory that the thinner the blade is, the greater the cutting force of the saw, as long as the firmness of the blade and cutting faces is maintained.

By making the blade thinner at the back than at the eutting edge-known as thin-backed saws-it has been possible to reduce the setting, without diminishing the free run of the blade. Hereby the refficiency is inereased, and the cut is better the less set the teeth are, as long as the blade runs free and there is no side-friction.

It must be noted that the making of thinner saw blades has only been possible through steady improvement of the quality of steel used. The modern single saw, which extperienced wood workers prefer, is how- ever, often so thin that much skill is required for us ing it without risk of breaking it by wrong handling.

With the "Sandvikers Kompisapparat," it has bee possible to use a thin blade with all its advantages in increased efficiency, without the risk of breaking th blade. It is also possible to use a longer blade, giving a larger and more effective cutting surface and mor effective incision than is produced with the ordinar. single saw.

This is a simple mechanism consisting of a spira spring, fastened to the end of the sawblade, which dur ing the sawing keeps the blade in even tension an, makes the guiding of the saw easier and gives a bette eut as well. The apparatus consists of two steel tubes of oval cross section, light and strong and fitting int each other. This double tube is finished at both end with claws to make it easier to fasten it to the groun. and to the tree. On the tube is placed an arm, adjust able in different directions, to which the spiral sprin is fastened. This arm can be adjusted by hand, with out any screwing, to the desired height. The whole ap paratus weighs six and one-half pounds. It can b

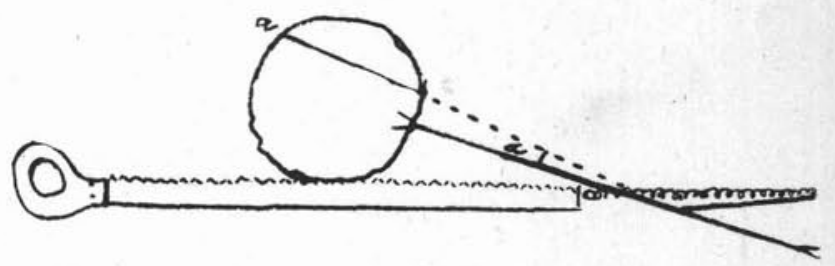

Fig. 2. The Kompisapparat used for cutting up logs.

used equally well for cutting up trees into $\operatorname{logs}$ or fo eutting down trees, and ean saw upwards as well a down.

With the "Apparat" are used special saws, of whicl the standard model is a single saw with a thin back straight teeth, finely tapered and with a distance be tween the bases of the teeth known as $P$ teething. Th more important measures are as follows: Thickmess 0 the blade, $.043^{\prime \prime}$ at the edge and about $.025^{\prime \prime}$ at th back; length of blade $3^{\prime} 9^{\prime \prime}$, width $234^{\prime \prime}$; distance be tween the points of the teeth $.4^{\prime \prime}$, between the base $.2^{\prime \prime}$; the angles of the teeth (the angles of the edg against the bases of the teeth) $71^{\circ}$ to $72^{\circ}$, setting $.006^{\prime \prime}$ the angles of the cutting face of the teeth $58^{\circ}$. Thi saw, however, is only made for use in connection wit this apparatus.

Extensive experiments have been carried on at th College of Forestry in Sweden, during 1925 and 1926 with the Kompisapparat and special saws, to determin the worth of the apparatus, and particularly to deter mine the best type of blade. These experiments wer commenced in June, 1925, at Malingsbo as a temporar undertaking, exhibiting the apparatus in action. I the following November, near Garpenberg, systemati tests were made with different tvoes of saw hlads 
In January, 1926, further experiments with definite standardised models of the apparatus were made at the large logging operations at Lidingö. The result of these experiments can be summed up as follows:

After several trials a standard model of the apparatus was decided upon-well-balanced in its details, strong and very serviceable and giving complete satis faction. The only part which requires, after a reasonable time, to be renewed is the spring, but this is to be expected and is easily done. On account of its light weight, the apparatus can be carried by the cutter without inconvenience; and it is very simple and easy to set up for work.

For cutting down trees, especially of average or large size, it is most useful, as well for increasing efficiency in sawing as for making the work easier for the men. In Fig. 4 are recorded some of the curves showiug the working results for the Garpenberg experiments, in connection with the saws of Type XII $\mathrm{N}$ and 25 .

The XII N saw is a common single saw of a 1924 model, which has been used with and without the new apparatus. The horizontal lines give the area and diameter of the sawed trees, and the vertical linies the time it took to saw the respective trunks.

On account of forced sawing during this experiment, the results show as higher than normal. It is noticeable, kowever, that the same saw used with the apparatus shows about double the sawing effect than when used in the ordinary way for which this saw is intended, on account of the regulating influence of the spiral spring on the blade, and the consequent better steering, saw$\log$ through a diameter of twelve inches.
In addition to this must be counted the greater fect which it is possible to obtain with the use of a t] ner and longer sawblade (entailing less friction : a larger cutting area); everyone will therefore is ize that considerable work is saved and better resi obtained with a special blade.

In Figure 5 are given sawing times for differ dimensions, and a number of special blades, as used the last experiments at Lidingö, where all the saw was done with the "Kompisapparat."

It is to be noted that these times, unlike the figr in Figure 4, were obtained by steady, regular work d by experienced woodworkers, and thus can be regar as normal results for log sawing in a temperature ( or 5 degrees (Réaumur) - about $40^{\circ} \mathrm{F}$.

As a comparison, saw No. 25 was used in both th experiments. Saw No. 23 in Figure 5 is the one alre described, which is accepted as the standard model this apparatus.

For sawing felled trees, the saving in effort by ing the apparatus is not so striking, but, particul for average anid large sizes, the trouble of placing apparatus is highly rewarded. Therefore, even if advantage is slight in comparison with that in usin for standing trees, the apparatus is well worth whj

From these extensive experiments and observati it may be concluded that the apparatus is an impor invention which should be popular with wood work It can now be obtained from the factory, address $\mathrm{S} \varepsilon$ vikens Jernverks A.-B., Sandviken, Sweden. The p of the apparatus with the special saw is approxima $\$ 5.60$, an extra saw without handle is $\$ 1.15$, and extra spring $50 \mathrm{c}$.

\section{Impressions of the World's Forestry Conference}

The World's Forestry Conference, held at Rome, April 29 to May 5, 1926, was described by C. S. Dana, of the American Forestry Association and head of the American delegation to the conference, as "The greatest gathering of foresters that has ever met." Delegates came from more than 50 countries, speaking many different languages; yes, even thinking in entirely different ways - their thoughts influenced largely by the development and economic conditions of the community from which they had come. Thus, the forester from southern Europe includes in his forest estimates all material, even to branchwood and twigs, and these are sold for fagots or for other uses, returning a considerable revenue; the northern foresters include stem and bark, but not branchwood; the American only that portion of stem that can be manufactured to a four-inch top in the East or to a 12 to 14-inch top on the Pacific Coast.

It is only after the most careful study of the vast amount of material included in the proceedings, covering 3500 pages, that one dare draw any definite conclusions from the work accomplished there. It seems, however, that the most important step taken at the conference was the recommendation for the establishment of a bureau for collecting and disseminating w forest statistics. The importance of this work is further emphasized by visiting the many forest a of Europe, viewing their choice bits of forest, and ing told that this or that area contains 700 or 800 bic meters per hectare, which, after calculating for duction in bark and branchwood, is equivalent to 000 board feet per acre. We had seen many sin acres in the Rocky Mountain region cruised at 15 to 20,000 board feet. Even traveling for a few mor stopping a day or two here and a day there, does give one sufficient data to form definite conclusi Impressions are formed however, and it is these sonal impressions that I give in reply to your inq regarding forest conditions in Europe.

\section{The Timber Supply of Europe}

Since the war the European cut is increasing will during the next few decades furnish more material than ever before. In southern Europe many years prior to the war the eut was regulater a very conservative basis. If the growth was esti ed at 10 cubic meters per hectare, the cut was rest ed to nine, the balance going to increase the $\mathrm{fc}$ capital. Now, due to many causes, the process 